\title{
CULTURAL ADAPTATIONS IN MAINTAINING RELIGIOUS HARMONY IN THE LABOR COMMUNITY AT PT SATYA KRISMA USAHA FACTORY IN TEBO ILIR JAMBI
}

\author{
Rara Anggraini ${ }^{*}$ \\ ${ }^{1}$ Institut Agama Islam Negeri Bukittinggi, West Sumatera, Indonesia, e-mail: rara123@,gmail.com \\ *Corresponding Author

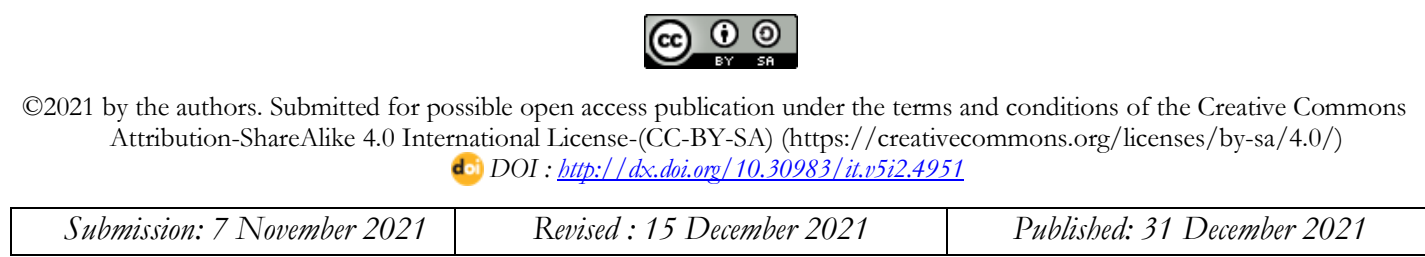

\section{Abstract}

This study describes the cultural adaptation carried out by the factory worker community consisting of various ethnicities and religions at PT Satya Krisma in Tebo Ilir Jambi, in maintaining religious harmony. This research uses qualitative research that emphasizes the depth of information obtained through interviews and is also supported by field observation methods. The results of the study show that first, the reality of life that occurs in the community of factory workers in the village of Betung Bedarah Barat is very harmonious and harmonious until now, because the community always respects and respects, and always prioritizes mutual assistance and cooperation. Second, factors that influence the occurrence of harmony are internal and external factors, internal factors are tolerance, dialogue between communities and there is also awareness of diversity. The external factor is that there are institutions that support religious harmony, namely the involvement of the government, traditional leaders and religious leaders. Third, in maintaining harmony, they have strategies including strengthening brotherhood, the role of traditional leaders, religious leaders, and maximizing regulations and the role of local governments.

Keywords: Cultural adaptations, labor community, Religious harmony

Abstrak
Penelitian ini menjelaskan tentang adaptasi budaya komunitas buruh pabrik dalam menjaga kerukunan umat
beragama di PT Satya Krisma di Tebo Ilir Jambi. Penelitian ini menggunakan jenis penelitian kualitatif yang
menekankan pada aspek kedalaman informasi yang diperoleh melalui wawancara dan didukung pula oleh
metode observasi lapangan. Hasilpenelitian menunjukekan bahwa pertama, realita kehidupan yang terjadi pada
komunitas buruh pabrik di desa Betung Bedarah Barat sangat rukun dan harmonis sampai saat ini, karena
masyarakat selalu menghargai dan menghormati, dan selalu mengedepankan sikap saling bantu dan bekerja
sama. Kedua, faktor yang mempengarubi terjadinya keharmonisan yaitu faktor internal dan eksternal, faktor
internal yaitu adanya sikap toleransi, dialog antar masyarakat dan juga terdapat kesadaran. Faktor eksternal
yaitu terdapat lembaga yang menjadi pendukung dalam kerukunan umat beragama yaitu adanya keterlibatan
pemerintah, tokoh adat dan tokoh agama. Ketiga, dalam mempertahankan kerukunan, mereka mempunyai
strategi di antaranya memperkuat tali persaudaraan, melibatkan tokoh adat, tokoh agama, dan
memaksimalkan peran regulasi pemerintah daerah.

Kata Kunci: Adaptasi budaya, Pekerja pabrik, Kerukunan umat beragama

\section{Background}

Inter-religious harmony is a situation in the life of fellow religious people based on tolerance, mutual understanding, mutual respect, respect for equality in the practice of their religious teachings, and cooperation in the life of society,

1 Latifah Latifah, Achwan Noorlistyo Adi, and Adila Afifah, "Pandangan Forum Kerukunan Umat Beragama Mengenai Makna Toleransi Antarumat nation and state within the Unitary State of the Republic of Indonesia in 1945 (PMB No. 8 and 9 of 2006) ${ }^{1}$. One of the most important forms of harmonization is tolerance, namely an attitude that is willing to accept the diversity of religions

Beragama di Jawa Barat," Jurnal Dakwah Risalah 30, no. 2 (2019): 136-53. 
and beliefs held by other religious parties or groups. Tolerance between religious communities has created harmony that makes life in religion very harmonious, because of mutual respect for one another ${ }^{2}$.

Therefore, this diversity must be preserved as a living unit that is not contaminated with skeptical superiority interests that undermine the meanings of a harmonious social life. In Gandhi's perspective, diversity can be a positive social capital if there is tolerance in it. Countries that are built with various ethnicities, religions, races, and so on, should maintain and build tolerance with various approaches, such as interreligious or interfaith dialogue, especially in the field of education. ${ }^{3}$

This interesting phenomenon of religious harmony was found in an area in the village of Betung Bedarah Barat. This village is inhabited by a community of PT Satya Krisma factory workers located in Tebo Ilir District, Tebo Regency, Jambi Province. The diversity of religious communities that characterizes this community began with the construction of a palm oil industry company that was founded in 1996. According to Zahria, since then, many people have come from different backgrounds and different ethnicities or religions ${ }^{4}$. Even though they come from different backgrounds, their harmonious life is still very well intertwined, so they can live side by side in peace. All people

2 Idrus Ruslan, Kontribusi Lembaga-Lembaga Keagamaan dalam Pengembangan Toleransi Antar Umat Beragama di Indonesia (Jakarta: Arjasa Pratama, 2020).

3 Silfia Hanani, "Studi Negosiasi Kultural Yang Mendamaikan Antaretnik dan Agama di Kota Tanjungpinang," Epistemé: Jurnal Pengembangan Ilmu Keislaman 12, no. 1 (2017): 201-30.

4 Ainun Zahria, Agus Fiadi, and Rahyu Zami, "Peranan Lembaga Adat dalam Melestarikan Budaya Lokal Masyarakat Desa Betung Bedarah Timur Kecamatan Tebo Ilir Kabupaten Tebo." (UIN Sulthan Thaha Saifuddin Jambi, 2020).

5 Amrin Nasution, (Non Muslim Community Leader) Interview, $\{21$ November 2020$\}$.

6 Yulmardi Yulmardi et al., "Where Is the Second Generation Nowadays? Evidence from Former Transmigration Villages in Jambi Province, Indonesia," Open Journal of Social Sciences 6, no. 4 (2018): 282-93. who live side by side, especially those with different religious backgrounds, can respect and help each other. This situation can be seen from every religious celebration, such as Islamic religious holidays, Eid al-Fitr, Chinese New Year, Christmas and others. The community respects and respects each activity carried out regardless of certain religious backgrounds. There is no difference in people's point of view ${ }^{5}$.

As an area for agricultural and industrial development, Jambi has become a target area for several ethnic groups in the archipelago, especially those from the island of Java in the transmigration program, as described in the research Yulmardi ${ }^{6}$, Miyamoko ${ }^{7}$, Frearnside ${ }^{8}$ and Harjono9. Interaction between ethnic and religious in this area is unavoidable. Differences in religion and background from the immigrant community and the local community do not make them hostile to each other, instead it makes the community open to each other and can accept local people and immigrants and create a harmonious and friendly social life with each other, regardless of status, religion, and ethnicity.

Ideally, ethnic and religious differences in society create understanding and acceptance of the culture and customs of each ethnic group and the existing beliefs of the community ${ }^{10}$. They can even exchange ideas, and give each other solutions to problems that occur. The interaction process that has been going on for a long time

${ }^{7}$ Motoe Miyamoto, "Forest Conversion to Rubber around Sumatran Villages in Indonesia: Comparing the Impacts of Road Construction, Transmigration Projects and Population," Forest Policy and Economics 9, no. 1 (2006): $1-12$.

8 Philip M Fearnside, "Transmigration in Indonesia: Lessons from Its Environmental and Social Impacts," Environmental Management 21, no. 4 (1997): 553 70.

9 Joan Hardjono, "Transmigration: Looking to the Future," Bulletin of Indonesian Economic Studies 22, no. 2 (1986): 28-53.

${ }^{10}$ Charles Hirschman, "The Role of Religion in the Origins and Adaptation of Immigrant Groups in the United States 1," International Migration Review 38, no. 3 (2004): 1206-33. 
makes it easier to carry out various activities together, such as in the case of mutual cooperation. The community can participate in any activity, regardless of religion and ethnicity, very openly and without limiting the interaction environment.

Previously, there have been many studies that explain the relationship between culture and religious harmony, religious harmony in the labor community in a factory or company, there are even studies on conflict in the factory worker community like Slaughter ${ }^{11}$ and Dermawan ${ }^{12}$. From these various studies, it was found that communities inhabited by several ethnicities and religions can be used as examples of the birth of religious harmony. This is because of the form of mutual cooperation in the construction of public facilities such as places of education and houses of worship. In addition, harmony can be realized because of the incorporation of local traditions that make people from various backgrounds able to live in harmony, even though there have been issues of religious conflict that have made relations between religious communities strained.

In addition, research has also been found that discusses the process of the emergence of religious harmony due to the influence of culture on society, like research Widodo ${ }^{13}$, Andayani ${ }^{14}$ and Purna ${ }^{15}$. These various studies explain the facts found in Indonesian culture in creating harmonious and harmonious relationships between religious adherents, harmonious and

11 Joseph P Slaughter, "Harmony in Business: Christian Communal Capitalism in the Early Republic," Enterprise \& Society 21, no. 3 (2020): 716-67.

12 Andy Dermawan and Zunly Nadia, "Etika Sosial dalam Kerukunan Umat Beragama (Studi Kasus di Desa Kotesan Kecamatan Prambanan Kabupaten Klaten Jawa Tengah)," Humanika, Kajian Ilmiah Mata Kuliah Umum 15, no. 1 (2015): 49-65.

13 Arif Widodo, "Nilai Budaya Ritual Perang Topat Sebagai Sumber Pembelajaran IPS Berbasis Kearifan Lokal di Sekolah Dasar," Gulawentah: Jurnal Studi Sosial 5, no. 1 (2020): 1-16.

14 Tri Rejeki Andayani, "Peningkatan Toleransi Melalui Budaya Tepa Salira (Pengembangan Model Pendidikan Karakter Berbasis Kearifan Lokal)," 2013. peaceful diversity activities, and solutions in the process of harmonization of relations between people with backgrounds of religious and ethnic differences. These various studies also found how inter-religious and inter-ethnic people can work together, and care for each other so that interactions can be well established.

Nevertheless, it is undeniable that there are problems in the interaction process such as conflicts and tensions in their social dynamics such as the research of Romli $^{16}$, Susilo ${ }^{17}$ and Sikwan ${ }^{18}$. These studies explain that in the context of different ethnic interactions between individuals and society, things that are not what can be avoided is the process of adaptation, assimilation and even conflict because of the dynamics that develop in their interaction process

Of the several studies conducted, most only focus on the issue of religious harmony in a multi-ethnic and multi-religious society. There was also a discussion about the role of culture in bringing about inter-religious harmony both in the community in general and in the labor and worker community in particular. However, research that highlights the process of cultural adaptation in maintaining religious harmony is still very limited. Therefore, in the process of multi-ethnic and multi-religious community interaction in the factory worker community at PT Satya Krisma Tebo Ilir, there has been a process of cultural adaptation in an effort to maintain religious harmony.

${ }^{15}$ I Made Purna, "Kearifan Lokal Masyarakat Desa Mbawa dalam Mewujudkan Toleransi Beragama," Jurnal Pendidikan dan Kebudayaan 1, no. 2 (2016): 261-77.

${ }^{16}$ Khomsahrial Romli, "Akulturasi dan Asimilasi dalam Konteks Interaksi Antar Etnik," Ijtimaiyya: Jurnal Pengembangan Masyarakat Islam 8, no. 1 (2015): 1-13.

17 Susilo Susilo, Nugraheni Irma Lusi, and Ana Mentari, "Analisis Interaksi Sosial terhadap Perilaku Masyarakat Pasca Konflik Antar Etnik di Kabupaten Lampung Selatan," Jurnal Civic Hukum 6, no. 1 (2021).

18 Agus Sikwan, "Dinamika Interaksi Antaretnik dalam Mewujudkan Keserasian Sosial di Wilayah Perbatasan Negara Indonesia-Malaysia," Jurnal Sosial Humaniora (JSH) 10, no. 2 (2017): 71-97. 
In this study, a qualitative method was used that emphasized the depth of information obtained through interviews with the factory worker community at PT Satya Krisma, which consisted of Javanese, Sundanese and Malay ethnicities. The religious diversity consists of Muslims and Christians. In addition, the researcher also interviewed supporting informants, namely the Head of Betung Bedarah Barat Village and the surrounding community. This interview data is supported by field observations observing the process of their social interaction.

Based on the explanation above, this article focuses on research on how this labor community adapts culturally in maintaining religious harmony with an article entitled "Cultural Adaptation in Maintaining Religious Harmony in the Factory Workers Community at PT Satya Krisma in Tebo Ilir Jambi". This article reveals how the relationship and interaction of religious people in this community, then also looks at the factors that make inter-religious communities can live in harmony. Also, look at the adaptation strategies carried out by the community in maintaining inter-religious harmony.

\section{Description of Betung Bedarah Village as a Multicultural area}

Betung Bedarah Barat Village is located in Tebo Ilir District, Tebo Regency, Jambi Province. The distance between the village of Betung Bedarah Barat and the center of the District of Tebo Ilir is about $\pm 9.5 \mathrm{~km}$ with a distance of about \pm 20 minutes. Access to transportation to Betung Bedarah Barat Village from the center of Tebo Regency can use motorbikes or cars with a distance of $\pm 52 \mathrm{~km}$ and a distance of \pm 60 minutes. To reach the

19 Maas M Maloha and Kanti Ratnaningrum, "Anopheles Mosquito Species in Betung Bedarah, Tebo Regency, Jambi Province," Magna Medika: Berkala Ilmiah Kedokteran dan Kesehatan 8, no. 1 (2021): 35-39.

${ }^{20}$ Yasrul Sami B Rahmad and Syafwan, "Suasana Kehidupan Masyarakat di Sekitar Sungai Batanghari dalam capital city of Jambi province in Telanaipura, the distance is $\pm 157 \mathrm{~km}$ with a travel time of about \pm 4 hours using cars and motorbikes ${ }^{19}$.

The origin of the naming of Betung Bedarah Barat Village comes from the story of bamboo drifting in the Batanghari River. At that time someone who saw the drifting bamboo heard the sound of crying coming from inside the bamboo. Then, the person was curious and broke the bamboo with a machete, then blood came out. From the story, this area is called Betung Bedarah Village ${ }^{20}$.

To ascertain the origin of the name, the researcher conducted interviews with village elders regarding the truth of the story of the origin of the name Betung Bedarah Barat. The results of the interview are:

It is true that there are stories about bamboo/reed drifting in the Batanghari river, and the blood flowing from inside the bamboo is true. Prior to the bamboo drifting incident, the village of Betung Bedarah Barat was only known as Dusun Lamo. So the name of this village means "Betung" is bamboo, "Bloody" is blood that comes out of a bamboo, and "West" is the location of the area to the west. ${ }^{21}$.

From an interview with the village elders of Betung Bedarah Barat, it can be concluded that the naming of the village comes from a surprising phenomenon, where there is a bamboo that can bleed, and it is a rare occurrence in human daily life. for the local community, this phenomenon is a true fact and has become a symbol that is highly valued by the community.

Betung Bedarah Village was founded in 1935, and is included in the administrative area of Bungo-Tebo (Bute) district. In 1977 the village of Betung Bedarah was divided into 2, namely West and East. After Bungo-Tebo

Seni Lukis Post Impresionis," Serupa The Journal of Art Education 6, no. 3 (2018), 32.

21 Zainal, (Traditional Leader Community) Interview, $\{21$ November 2020$\}$ 
district underwent division on October 12, 1999 into Bungo district and Tebo district, the village of Betung Bedarah Barat was included in the administrative area of Tebo district. The village of Betung Bedarah Barat consists of three hamlets, namely hamlets I, II, and III which consist of 14 Neighborhoods. In the days of the Hindu-Buddhist kingdom, the village of Betung Bedarah Barat was led by a clan head called the Pasirah, then briefly changed to a lurah, and now it has changed to a village head ${ }^{2223}$.

\section{Description of the Reality of Relations Between Muslim and Christian Communities in Betung Bedarah Barat Village}

The Betung Bedarah West community is a society that previously embraced Islam as a whole, before the arrival of immigrants from various regions. After the palm oil industry company PT Satya Kisma Usaha was established in Betung Bedarah Barat, since then outsiders began to arrive from various regions, one of which was non-Muslim communities. Until now, the population of Betung Bedarah Barat village as a whole is not only the Muslim community but also the non-Muslim community. In Tebo Regency, precisely in Tebo Ilir Subdistrict, Christians are mostly found in Tebo Ulu, Tebo Tengah and Tengah Ilir Subdistricts, because oil palm companies first established in this place than in other places, so Christians are more common. However, although the number of Christians is quite large, there has never been a conflict between religions.

With the influx of immigrants from various regions into this region, the village of Betung Bedarah Barat is not only dominated by one religion but also other religions with various

22 Rudi Etnovian Hadi Kurniawan, "Strategi Pengusaha Bangsal Genteng Tradisional dalam Memanage Risiko di Kecamatan Tebo Ilir Jambi Menurut Perspektif Ekonomi Islam" (Universitas Islam Negeri Sultan Syarif Kasim Riau, 2013), p. 12. sects. Not only religion, but also there are various ethnic groups with different cultural backgrounds.

Among these immigrants there are Minangkabau, Javanese, Batak and others. Their main purpose in coming to the village of Betung Bedarah Barat is because of economic factors. Even though the newcomers are not Muslim or Malay, the local community still accepts them with open arms and maintains good relations with each other.

Relations between the people in the village of Betung Bedarah Barat are still safe and there are no conflicts or hostility. As an interview with Mr. Kuspandi as the Head of the West Betung Betung Village, related to how the relationship between Muslim and non-Muslim communities in the Betung Bedarah West area, namely:

Since the establishment of PT in 1996 until today, migrants from various regions have continued to arrive. Society is becoming more and more plural, but relations between communities, both Muslim and non-Muslim, run peacefully, and there has never been a conflict in the name of religion, ethnicity, culture and others. Relations between communities continue to run harmoniously. ${ }^{24}$

From the interview, it can be clearly seen that the pluralistic Betung Bearah community relations are still harmoniously intertwined, side by side and live in harmony with each other without any distinction from one another.

This harmonious relationship cannot be separated from the religious teachings adopted by every society. The Betung Bedarah community, who is Muslim, believes that Islam teaches mutual respect for the beliefs of others, and regulates good relations between humans and their God, humans with other humans, and

23 Mimi Lasmita and Rara Anggraini, "Eksistensi dan Pencitraan Politikus dalam Mitigasi Bencana Banjir di Betung Bedarah Tebo Ilir Provinsi Jambi," Turast: Jurnal Penelitian dan Pengabdian 7, no. 2 (2019): 127-44.

${ }^{24}$ Kuspandi, (The Village Head of Betung Bedarah Barat) Interview, $\{13$ April 2021\} 
humans with other creatures. Meanwhile, the Christian community also has the same teachings so that in social life they can live in harmony with each other and always seek peace. So, of course, it is very clear that in reality the Betung Bedarah community has remained harmonious without any conflict until now.

Muslim and non-Muslim communities in the Betung Bedarah Barat area also work together to maintain and protect the unity that exists in society. The community also shows the social side of each of them to help each other and work together in building harmony between religious communities.

In a society that has differences, it does not make people reluctant to establish good relationships, which can be seen between the people there is an attitude of helping each other and working together in everyday life. In this case, the researcher conducted direct interviews with the Christian community about life based on a high social sense, always working together and mutual respect for each other, as the results of interviews with Mr. Holmen Manurung, namely:

In social life, the existence of religious differences does not make the existing harmony disappear, it only strengthens us to help each other and work together. Both Muslim and Christian they always help each other, That's the family bond that we feel as Christians. ${ }^{25}$

This study relies on interview sources, especially those from the Christian community. He is Holmen Manurung, 41 years old and has a wife named Erony Boru Siadari. They have two daughters named Grace Nova Boru Manurung and Stefaniy Boru Manurung. Mr. Manurung is a Christian immigrant community. Based on the results of an interview with Mr. Holmen, it was

25 Holmen Manurung (Non-Muslim Migrant Society) Interview, $\{13$ April 2021\}. found that the people of Betung Bedarah Barat do not differentiate between people from their religion, and the community has great respect for other people, which can be seen in their mutual help in the Betung Bedarah community.

Based on observations and interviews that researchers have conducted regarding the reality of religious harmony in the factory worker community in Betung Bedarah Barat, it is clear that in the village of Betung Bedarah Barat, Tebo Ilir District, Tebo Regency, Jambi Province, inter-religious harmony and harmony are clearly seen in daily life. day. The interacting communities are people who come from different beliefs, cultures, languages and ethnicities, where in each community an attitude of caring, mutual respect and tolerance for others is instilled so that people always live in harmony and peace.

The evidence that harmony has persisted to this day is seen from the community in interacting, helping each other and establishing good relationships among the community. Other evidence can also be seen from direct interviews with the people of Betung Bedarah Barat, both Muslims and non-Muslims who live side by side.

Several explanations from the results of interviews and observations are in line with Victoria research, which from this theory explains that from differences in society, mutual respect, mutual respect and tolerance are needed in society because they live side by side with different communities. Therefore, the differences that exist are highly regulated in social integration which forms a different element in society so as to create a pattern of life that has harmonious functions and creates harmony from existing differences ${ }^{26}$.

${ }^{26}$ Mabelle Victoria, "Power and Politeness: A Study of Social Interaction in Business Meetings with Multicultural Participation," ESP across Cultures 40 (2009): 129-40. 


\section{Cultural Adaptation Strategy in Maintaining Religious Harmony}

The harmony that is created in the factory worker community in the Betung Bedarah Barat village community certainly has its own way so that the people still have good relations with each other even though they have differences. In that strategy are:.

\section{Keeping the Brotherhood}

One way to maintain the brotherhood is to strengthen the sense of tolerance among religious people. With a high sense of tolerance, relations with each other will be maintained and harmonious between fellow religious people will be maintained. Where the social life of religious people is always tied with ties of brotherhood, both fellow Muslims and non-Muslims.

Maintaining the ties of brotherhood among religious people is certainly present in every religious teaching that is believed, such as the results of an interview with Mr. Donanta Bagun, namely:

"In Christian teaching there is also a bond of brotherly love, in our book we are also taught about brotherly love, where we hold fast to the teaching which says that our brothers and sisters are fellow believers and fellow human beings, no matter where they come from, so that we can still love each other"27

From the results of the interviews above, it can be seen that there are efforts to adapt religious teachings made by Christians in understanding tolerance and brotherhood. All teachings certainly teach to take care of and protect each other, and keep the ties of brotherhood between each other.

From all the explanations, it can be seen that it is very necessary to foster a brotherly

\footnotetext{
${ }^{27}$ Donanta Bangun (Non-Muslim Migrant Society) Interview, \{14 April 2021\}

${ }^{28}$ Dewi Tika Lestari, "Merawat Harmoni Agama Melalui Kolaborasi Musik Hadroh dan Trompet di Ambon," Religious: Jurnal Studi Agama-Agama Dan Lintas Budaya 4, no. 3 (2020): 215-26.
}

attitude among fellow believers without making the slightest difference between religious backgrounds. There is no difference except in terms of worship and adhere to beliefs. If a sense of brotherhood has grown in us, of course we feel we are family, and we can sympathize and empathize with each other. This is in line with Lestari $^{28}$ and Makaruku's ${ }^{29}$ research on multicommunity in Maluku, through art and brotherhood bonds will create harmony in society. Therefore, in creating harmony between religious communities, maintaining brotherly ties is very necessary in establishing harmonious relations between religious communities.

The presence of brotherhood is always maintained, the community will always live in harmony and harmoniously and there will be no conflict, both religious, cultural, race and other conflicts. As reinforced by the results of interviews by the Village Head, namely:

"Communities are always encouraged to maintain and respect each other, because with such an attitude, the community will always live harmoniously, harmoniously and guard each other even though there is no blood relationship but will always keep up with each other. ${ }^{30}$

From the results of interviews delivered by the Village Head, of course it can be seen that the government also always appealed to the community to always maintain the brotherhood between others so that the conflict is not. From here it can be seen that maintaining each other's brotherhood can be one way to avoid conflict occurrence. Even according to Sena, a more

${ }^{29}$ Nathalia Debby Makaruku, Izak Y M Lattu, and Tony Robert C Tampake, "Keterlibatan Masyarakat dalam Membangun Harmoni Sosial Muslim-Kristen Pra dan Pasca Konflik Etnik di Maluku," Islamica: Jurnal Studi Keislaman 15, no. 1 (2020): 68-91.

${ }^{30}$ Kuspandi, (The Village Head of Betung Bedarah Barat) Interview, \{April 2021\}. 
intense brotherhood can be a strong basis and reason for creating religious harmony ${ }^{31}$

The Role of Traditional and Religious Leaders in The Application of Tolerance in The Community

Studies of the role customary and religious leaders are certainly a key in the process of cultural adaptation in every community life done a lot such as Affandi $^{32}$, Mustofa ${ }^{33}$ and Alifuddin ${ }^{34}$, where to build a harmonious society is certainly necessary to process a culture adaptation, how traditional leaders even religious leaders as customer and traditions they make efforts to adjust and negotiate in the form of adaptation. The role of each customary and religious institutions is very necessary, because traditional leaders and religious leaders play an important role in creating a harmonious society. Like giving sanctions for legal violators and other.

All institutions that exist in people's daily lives, of course have their own way of controlling and of course have ways of solving the problem, as said by the chairman of the Customary Institution, namely:

"We have our own ways and processes at each institution in solving problems that exist in society, so that people can still live side by side and live in harmony, for that so far the traditional leaders who have been chosen have played a very important role in protecting the community from problems. -problems that lead to division" 35 .

From the interview above, it can be seen that everything related to comfort and harmony

31 I Gusti Made Widya Sena, "Peran Umat Hindu dan Kristen dalam Menjaga Toleransi Kehidupan Masyarakat di Kota Kupang Nusa Tenggara Timur," Harmoni 19, no. 1 (2020): 100-114.

32 Nurkholik Affandi, "Harmoni dalam Keragaman (Sebuah Analisis Tentang Konstruksi Perdamaian Antar Umat Beragama," Lentera 14, no. 1 JUNI (2012): 12.

33 Imam Mustofa, "Peran Organisasi Masyarakat dalam Membangun Harmoni Pasca Konflik Antara Masyarakat Pribumi dengan Masyarakat Pendatang di Lampung Tengah," Penamas 31, no. 1 (2018): 205-26.

34 Muhammad Alifuddin, "Dakwah Berbasis Multikultur (Paradigma dan Strategi Tokoh Agama dalam between communities has been highly guarded and protected in the daily life of the people themselves, all existing institutions also play an active role in maintaining a diverse community environment in order to remain harmonious and live in harmony among people. other.

The involvement of customary and religious leaders can be seen from the role given by each religious leader and traditional figure. That is, it can reflect every action to the community so that people follow every good action. Like the actions given by religious leaders, namely forbidding alone together before there is a legitimate bond ${ }^{36}$.

Religious leaders as trusted people, appointed and chosen directly by the community. Therefore they have believed that the characters chosen will be fair and balanced in making every follower of their respective religions. The existence of the chosen figures is also a way of the regional government in strengthening the objectives of every society, namely creating harmony and harmony between people through a moderation of religious attitudes in society ${ }^{37}$.

Although involving both institutions, namely customs and religion, it does not mean forgotten the role of the local government, but with this institution, it will further strengthen the foundation in the community, because a government institution that stands cannot be separated from the role of religious leaders and indigenous leaders. Therefore the involvement

Membangun Harmoni Antar Iman di Kendari)," Jurnal Dakwah 16, no. 1 (2015): 37-57.

${ }^{35}$ Zainal, (Traditional Leader Community) Interview, $\{21$ November 2020$\}$

36 Ibnu Rusydi and Siti Zolehah, "Makna Kerukunan Antar Umat Beragama dalam Konteks Keislaman dan Keindonesian," Al-Afkar, Journal for Islamic Studies 1, no. 1, January (2018): 170-81.

37 Ramadhanita Mustika Sari, "Keharmonisan dalam Kehidupan Umat Beragama Perspektif Pendeta di Indonesia," Jurnal Studi Agama 4, no. 1 (2020): 1-14. 
of religious and customary institutions is very important in a government.

\section{Maximum Implementation of Regulation and The Role of The Government}

In building a strategy so that the community remains harmonious, the West Betung Village Government always supervises the community not to take actions that tend to conflict. The local government participates in doing the best for the community to stay in harmony and peace.

The government also always protects and gives an example for the community not to act in the direction that will cause a dispute, because if the dispute occurs, an area or village will experience destruction. Regional leaders directly always appeal to people to always maintain and communicate openly between fellow societies well. As the results of interviews with researchers with village heads, and the results of interviews conducted by researchers with Kuspandi, the village head:

"I always appeal to people to every opportunity I deliver a speech at every event, so that people must maintain and protect each other, respect each other, because we are brothers. So don't do things that fishing the commotion especially related to racism and others. Let's embrace each other, protect each other and always live in harmony". ${ }^{38}$

From the results of the interview delivered by Kuspandi as the village head, that to maximize and maintain the community to live in harmony and peace, it is necessary to have a racist invitation to anyone and guard each other. In addition to the invitation, in maximizing government regulation in building strategies is to strive to always resolve any problems faced by society well ${ }^{39}$.

${ }^{38}$ Kuspandi, (The Village Head of Betung Bedarah Barat) Interview, $\{14$ April 2021\}.
In a strategy to form a harmonious society, the government has always become the leading guard for its people. The government strengthens all institutions related to society and affects all of its people, such as religious leaders, traditional leaders. In strengthening all these institutions, the West Betung Village Government emphasized that each institution teaches and invites the public to be able to understand the difference and maintain the brotherhood of the community. This method is considered effective to maintain harmony between religious people.

In addition to the form of mutual respect between others, a fair attitude of a leader is also a separate way for the community to view equally fellow, with a fair attitude and provide equality to the community, it can be a driving force to live in harmony and peace. With harmony and harmonious living in socializing society so that the people do not discriminate others based on their background and beliefs

\section{Conclusion}

Based on the research conducted in Betung Bedarah Barat Village, Tebo Ilir Subdistrict, Jambi Province with the research of religious harmony, therefore the writer can conclude several things as follows, first: In a multicultural area, the achievement of the harmony between the people of Betung Betung Betung in which there is cooperation Intersocieties both Muslims and non-Muslims, and the presence of mutual respect for each other so that everything happens in the community is resolved and worked together. The dissemination that occurs in the people of Betung Village, Western Ballarah is also based on mutual understanding, and the attitude of openness to other communities regardless of differences in each other. So that the attitude that

39 Alfina Prayogo, Esther Simamora, and Nita Kusuma, "Peran Pemerintah dalam Upaya Menjaga Kerukunan Umat Beragama di Indonesia," Jurist-Diction 3, no. 1 (2020): 21-36. 
underlies is one of the forming the creation of harmony between religious people. The reality that is also seen does not come out of the existing rules, so it is clear that it is clear until now the circumstances and conditions of people live in harmony and peace. Second, the strategies used in maintaining the harmony between religious people, there is a need for acting so that there is no dispute and dispute in the name of religion, including always strengthening the brotherhood between communities both Muslims and nonMuslims regardless of differences. In addition, the strategy that also greatly influences the harmony of religious people needs to be involvement in traditional and religious leaders, because indigenous leaders regulate all actions carried out by the community and religious leaders into role models for every society. Then another step is by strengthening the role of the government to make a harmonious and harmonious society, the efforts made in forming are prioritizing and strengthening all institutions related to both religious institutions, customs, and regulations in the community. The government also encouraged figures who were role models of each follower to always guide their people, so that the community felt comfort and peace in society.

\section{References}

Affandi, Nurkholik. "Harmoni dalam Keragaman (Sebuah Analisis tentang Konstruksi Perdamaian Antar Umat Beragama," Lentera 14, no. 1 (2012): 21.

Alifuddin, Muhammad. "Dakwah Berbasis Multikultur (Paradigma dan Strategi Tokoh Agama dalam Membangun Harmoni antar Iman di Kendari)," Jurnal Dakwah 16, no. 1 (2015): 37-57.

Andayani, Tri Rejeki. "Peningkatan Toleransi Melalui Budaya Tepa Salira (Pengembangan Model Pendidikan Karakter Berbasis Kearifan Lokal)," 2013.

Dermawan, Andy, and Zunly Nadia. "Etika Sosial dalam Kerukunan Umat Beragama
(Studi Kasus di Desa Kotesan Kecamatan Prambanan Kabupaten Klaten Jawa Tengah)." Humanika, Kajian Ilmiah Mata Kuliah Umum 15, no. 1 (2015): 49-65.

Fearnside, Philip M. "Transmigration in Indonesia: Lessons from Its Environmental and Social Impacts." Environmental Management 21, no. 4 (1997): 553-70.

Hanani, Silfia. "Studi Negosiasi Kultural yang Mendamaikan Antaretnik dan Agama di Kota Tanjungpinang." Epistemé: Jurnal Pengembangan Ilmu Keislaman 12, no. 1 (2017): 201-30.

Hardjono, Joan. "Transmigration: Looking to The Future." Bulletin of Indonesian Economic Studies 22, no. 2 (1986): 28-53.

Hirschman, Charles. "The Role of Religion in the Origins and Adaptation of Immigrant Groups in the United States 1." International Migration Review 38, no. 3 (2004): 1206-33.

Kurniawan, Rudi Etnovian Hadi. "Strategi Pengusaha Bangsal Genteng Tradisional dalam Memanage Risiko di Kecamatan Tebo Ilir Jambi Menurut Perspektif Ekonomi Islam" (Universitas Islam Negeri Sultan Syarif Kasim Riau, 2013)

Lasmita, Mimi, and Rara Anggraini. "Eksistensi dan Pencitraan Politikus dalam Mitigasi Bencana Banjir di Betung Bedarah Tebo Ilir Provinsi Jambi." Turast: Jurnal Penelitian dan Pengabdian 7, no. 2 (2019): 127-44.

Latifah, Latifah, Achwan Noorlistyo Adi, And Adila Afifah. "Pandangan Forum Kerukunan Umat Beragama Mengenai Makna Toleransi Antarumat Beragama di Jawa Barat." Jurnal Dakwah Risalah 30, no. 2 (2019): 136-53.

Lestari, Dewi Tika. "Merawat Harmoni Agama Melalui Kolaborasi Musik Hadroh dan Trompet di Ambon." Religious: Jurnal Studi Agama-Agama dan Lintas Budaya 4, no. 3 (2020): 215-26.

Makaruku, Nathalia Debby, Izak Y M Lattu, And Tony Robert C Tampake. "Keterlibatan Masyarakat dalam Membangun Harmoni Sosial Muslim-Kristen Pra dan Pasca Konflik Etnik di Maluku." Islamica: Jurnal 
Studi Keislaman 15, no. 1 (2020): 68-91.

Maloha, Maas M, And Kanti Ratnaningrum. "Anopheles Mosquito Species in Betung Bedarah, Tebo Regency, Jambi Province." Magna Medika: Berkala Ilmiah Kedokteran dan Kesehatan 8, No. 1 (2021): 35-39.

Miyamoto, Motoe. "Forest Conversion to Rubber Around Sumatran Villages in Indonesia: Comparing The Impacts of Road Construction, Transmigration Projects and Population." Forest Policy and Economics 9, No. 1 (2006): 1-12.

Mustofa, Imam. "Peran Organisasi Masyarakat dalam Membangun Harmoni Pasca Konflik Antara Masyarakat Pribumi dengan Masyarakat Pendatang di Lampung Tengah," Penamas 31, no. 1 (2018): 205-26.

Prayogo, Alfina, Esther Simamora, And Nita Kusuma. "Peran Pemerintah dalam Upaya Menjaga Kerukunan Umat Beragama di Indonesia." Jurist-Diction 3, no. 1 (2020): $21-$ 36.

Purna, I Made. "Kearifan Lokal Masyarakat Desa Mbawa dalam Mewujudkan Toleransi Beragama." Jurnal Pendidikan dan Kebudayaan 1, no. 2 (2016): 261-77.

Rahmad, Yasrul Sami B and Syafwan, "Suasana Kehidupan Masyarakat di Sekitar Sungai Batanghari dalam Seni Lukis Post Impresionis," Serupa The Journal of Art Education 6, no. 3 (2018): 32

Romli, Khomsahrial. "Akulturasi dan Asimilasi dalam Konteks Interaksi antar Etnik." Ijtimaiyya: Jurnal Pengembangan Masyarakat Islam 8, no. 1 (2015): 1-13.

Ruslan, Idrus. Kontribusi Lembaga-Lembaga Keagamaan dalam Pengembangan Toleransi Antar Umat Beragama di Indonesia. Jakarta: Arjasa Pratama, 2020.

Rusydi, Ibnu, And Siti Zolehah. "Makna Kerukunan Antar Umat Beragama dalam Konteks Keislaman dan Keindonesian." Al-Afkear, Journal for Islamic Studies 1, no. 1, January (2018): 170-81.

Sari, Ramadhanita Mustika. "Keharmonisan dalam Kehidupan Umat Beragama Perspektif Pendeta di Indonesia." Jurnal
Studi Agama 4, no. 1 (2020): 1-14.

Sena, I Gusti Made Widya. "Peran Umat Hindu dan Kristen dalam Menjaga Toleransi Kehidupan Masyarakat di Kota Kupang Nusa Tenggara Timur." Harmoni 19, no. 1 (2020): 100-114.

Sikwan, Agus. "Dinamika Interaksi Antaretnik dalam Mewujudkan Keserasian Sosial di Wilayah Perbatasan Negara IndonesiaMalaysia." Jurnal Sosial Humaniora (JSH) 10, no. 2 (2017): 71-97.

Slaughter, Joseph P. "Harmony In Business: Christian Communal Capitalism in The Early Republic." Enterprise \& Society 21, no. 3 (2020): 716-67.

Susilo, Susilo, Nugraheni Irma Lusi, And Ana Mentari. "Analisis Interaksi Sosial terhadap Perilaku Masyarakat Pasca Konflik antar Etnik di Kabupaten Lampung Selatan.” Jurnal Civic Hukum 6, no. 1 (2021).

Victoria, Mabelle. "Power and Politeness: A Study of Social Interaction in Business Meetings with Multicultural Participation." Esp Across Cultures 40 (2009): 129-40.

Widodo, Arif. "Nilai Budaya Ritual Perang Topat Sebagai Sumber Pembelajaran IPS Berbasis Kearifan Lokal di Sekolah Dasar." Gulawentab: Jurnal Studi Sosial 5, no. 1 (2020): 1-16.

Yulmardi, Yulmardi, Amri Amir, Erfit Erfit, and Junaidi Junaidi. "Where Is The Second Generation Nowadays? Evidence from Former Transmigration Villages in Jambi Province, Indonesia." Open Journal Of Social Sciences 6, no. 4 (2018): 282-93.

Zahria, Ainun, Agus Fiadi, and Rahyu Zami. "Peranan Lembaga Adat dalam Melestarikan Budaya Lokal Masyarakat Desa Betung Bedarah Timur Kecamatan Tebo Ilir Kabupaten Tebo." UIN Sulthan Thaha Saifuddin Jambi, 2020.

\section{Interviews}

Amrin Nasution, (Non Muslim Community Leader) Interview, $\{21$ November 2020$\}$.

Donanta Bangun, (Non-Muslim Migrant Society) Interview, $\{14$ April 2021$\}$ 
Holmen Manurung, (Non-Muslim Migrant Society) Interview, $\{13$ April 2021\}.

Kuspandi, (The Village Head of Betung Bedarah Barat) Interview, \{13 April 2021\}
Zainal, (Traditional Leader Community) Interview, $\{21$ November 2020$\}$. 